\title{
THE ROLE OF THE PUBLIC EMPLOYMENT SERVICE IN THE UNEMPLOYMENT COMPENSATION PROGRAM
}

\author{
WILLIAM H. STEAD*
}

It would appear inevitable to any student of the problem of administration of unemployment compensation that the public employment service must be closely coördinated with the administrative machinery provided to carry out such an enterprise. The entire history of European experience with various forms of unemployment insurance indicates the essential nature of this relationship, and it was recognized by Congress in passing the Social Security Act through the inclusion of a provision that the payment of unemployment compensation benefits should be through public employment offices or other agencies approved by the Social Security Board. ${ }^{1}$

In the preliminary development of plans for administration of unemployment compensation, the Social Security Board seems to be contemplating the exclusive use of the Employment Service for these purposes. It therefore is pertinent to inquire with respect to the possible nature of such relationships and the part which the Employment Service should play in this program.

\section{Organization of the United States Employment Service}

Since the United States Employment Service is an existing nation-wide organization at the moment when the unemployment compensation machinery is being developed, it is essential to understand the nature of that organization as a basis for

* B.A., 1920, Beloit; M.A., I923, University of Chicago; Ph.D., 1926, University of Minnesota. Associate Director, in charge of the Division of Standards and Research, United States Employment Service, since 1933. Instructor, Assistant Professor, and Associate Professor of Economics, University of Minnesota, 1923-1933, in charge of courses in personnel management and labor; responsible for placement work of graduates; consulting and personnel relations in the Twin Cities; Executive Secretary of the Minnesota Employment Stabilization Research Institute and Head of the Tri-City Committee, 1930-r933. Representative of the Secretary of Labor at Technical Placing Conference and the International Labor Conference, Geneva, Switzerland, May and June, 1933. Contributor to economic, statistical, and occupational magazines. Editor of Employment Office Manual Series and industrial job specification series of the United States Employment Service.

${ }^{1}$ The Social Security Act of Aug. I4, 1935, Public, No. 271, 74th Cong., Ist Sess., tit. IX, $\$ 903$ (a) (I), provides: "The Social Security Board shall approve any State law submitted to it ... which it finds provides that-(I) All compensation is to be paid through public employment offices in the State or such other agencies as the Board may approve; ..." 
suggesting the possible adjustments of the Service to fit into this newer and larger program.

The present United States Employment Service resulted from the passage of the Wagner-Peyser Act on June 6, $1933{ }^{2}$ providing for the creation of a federally coördinated system of state employment services, supported jointly by state and federal funds, on a matching basis. Since July I, I933, the number of state employment services in existence has increased from 23 to 36 , with an additional 5 states having authorized the setting up of an employment service but with no appropriation as yet for the support of this service. ${ }^{3}$ The number of local or district employment offices included in these state services has increased from I35 on July I, I933, to 232 as of December 3I, I935. These offices have been materially enlarged and improved with respect to premises, layout, and equipment, the personnel has been qualified for their present positions on the basis of merit examinations, and a general training and developmental program has proceeded as rapidly as possible in view of the interruptions occasioned by handling large emergency public works programs. At the same time that the Wagner-Peyser Act was passed creating the United States Employment Service, the National Industrial Recovery Act in Title 2, setting up the public works program, required that the United States Employment Service make available an agency for serving the needs of the public works program in every part of the country.

The United States Employment Service was able to designate the existing state offices to serve the areas in their immediate vicinity, but it became necessary to create an emergency federal division of the Employment Service, known as the National Reëmployment Service, to serve the balance of the areas, which throughout the fiscal years I934 and I935 constituted the great bulk of the territory and a large percentage of the population of the entire country. The National Reëmployment Service, starting on a basis of county offices, had a total of $x 800$ local offices organized by November I, I933 to serve public works projects in various parts of the country. With the coming of the Civil Works Administration in November, the number of local county offices increased to $328 \mathrm{I}$, providing a minimum of at least one office in each county. Upon conclusion of the C. W. A. program in March, I934, the entire United States Employment Service organization, both affiliated state services and the National Reëmployment Service, was reorganized and consolidated into something over 800 district offices, each district serving one or more counties. The entire area of the country was included in the service provided through these district offices. A number of local branch offices were continued in each district. Since that period, the district form of organization has been developed and consolidated so that at present a district organization of 722 offices, of which 232 are in the affiliated state-

${ }^{2} 48$ StsT. 114,29 U. S. C. A. (Supp.) c. ${ }_{4}$ C.

- The seven states in which no state employment services have been authorized are Kansas, Maine, Maryland, Michigan, Mississippi, Montana, South Carolina. 
federal system and 490 are N.R. S. district offices, serves the entire country. As of December 3r, 1935 , there were 1366 local branch offices in these 722 districts.

The coming of the W.P. A. program in the latter half of 1935 occasioned another major increase in the number of branch offices and the number of personnel essential in the district offices. No basic change in the structure of the Employment Service has resulted from these recent major changes in the volume of work handled to serve the various public works and work relief programs. It may be fairly stated, therefore, that there is in existence as of January $\mathbf{I}$, 1936 , an employment service system serving every area in the nation, with the number of permanent affiliated state-federal offices gradually increasing in number and taking over districts served by the temporary emergency N. R. S. as rapidly as appropriated funds permit.

\section{Administrative Relationships Between the Emsloyment Service and the Unemployment Compensation Program.}

A. Federal Administration.

It is not possible at the moment to indicate the ultimate nature of the administrative relationships which will be set up to coördinate the activities of the Employment Service and that division of the Social Security Board concerned with the administration of unemployment compensation. At the present time the United States Employment Service is a regular bureau of the Department of Labor, whereas the Social Security Board is an independent agency, not directly related to any of the major government departments.

It seems inevitable that the close relationships which must be developed between the Employment Service and the Security Board will eventually lead to some definite form of administrative integration in Washington, but what that ultimate form might be is uncertain. The necessity for such administrative integration becomes apparent when it is realized that the administrative arrangements within a typical state provide for practical consolidation of the administration of unemployment compensation and the Employment Service within the structure of the state government, providing one coördinated agency within the state, with which the United States Employment Service and the Social Security Board must each have direct administrative relationships.

Pending the development of formal administrative relationships, efforts are being made by the Security Board and the United States Employment Service in the Department of Labor in the interests of developing a closely coördinated plan of operation. Thus the development of the field organization to serve the needs of the Security Board, including regional and district offices, is in large part based on the existing district office structure of the Employment Service and grows out of experience in the evolution of these Employment Service districts.

It is anticipated that whatever regional offices may be established by the Social Security Board for purposes of administration and supervision will be paralleled by 
regional offices of the United States Employment Service. There has likewise been agreement in the drafting of suggested model state acts for the administration of unemployment compensation and employment service, so that it may be said that whatever the final form of administrative integration between the Social Security Board and the United States Employment Service, preliminary planning of functions is designed to facilitate such an integration.

\section{B. State Administration.}

The suggested model state acts recently made available to the various state governments by the Social Security Board for such use as the states may wish to make of them in planning their own programs, have suggested three alternative plans for integration of the work of the Employment Service and the unemployment compensation administration. ${ }^{4}$ Alternative number one suggests the creation of an unemployment compensation commission independent of any existing state agencies with two coördinated divisions, one to administer unemployment compensation proper and the other to administer the employment service and to maintain necessary relationships with the United States Employment Service. Alternative number two, suggests that under an existing department of labor or industrial commission there be created an unemployment compensation and employment service division to administer both of these functions with two sections in this division, one for unemployment compensation administration and one for employment service administration, with each of these sections performing functions similar to those of the divisions in plan one. Alternative number three provides that where there exists a department of labor or industrial commission with a state employment service as a division under such commission, there be created a coördinate division under such department of labor or industrial commission for the administration of unemployment compensation.

It is therefore suggested that in one of these three ways close coördination of the functions in administration of unemployment compensation and the employment service may be secured, while at the same time the distinct character and functions of each activity are clearly maintained and protected. There is always the risk, as has been shown in European experience, that in discharging the functions assigned to it in serving unemployment compensation, the public employment service may become a mere routine service agency devoted almost exclusively to the needs of the compensation program. It is extremely important that the placement functions including the development of relationships with private employers, and the effort to do a first class personnel job in the classification of workers and their effective readjustment into private employment, which are the major functions of an employ-

\footnotetext{
'Soc. Sec. Bd., Draft Bills for State Unemployment Compensation of Pooled Fund and Employer Reserve Type (Jan. 1936), \$\$10, 12.
} 
ment service, should be protected and not subordinated to the needs of the compensation program.

It is believed that the suggested types of administrative organization proposed in these acts will adequately care for this situation. In the unemployment compensation laws now in existence in a number of states, these several alternatives are exemplified. Thus in the state of Wisconsin under the existing industrial commission there are two coördinate but independent divisions, namely, the state employment service, affiliated with the United States Employment Service, and the unemployment compensation division. In the state of New York the act provides for a division of unemployment compensation in the department of labor and under this division there are two coördinate sections, one for unemployment compensation administration and the other comprising the New York State Employment Service, affiliated with the United States Employment Service. Another variation is found in the Massachusetts law creating an unemployment compensation commission under the department of labor but not responsible to it, said unemployment compensation commission having two coördinate divisions, one for unemployment compensation administration and the other the Massachusetts State Employment Service, affiliated with the United States Employment Service.

There will undoubtedly be many variations of the suggested alternatives outlined above in the laws as passed by the several states. The existing state precedents and the recommendations of the Social Security Board would seem to indicate that some such pattern of administrative relationships will be developed in the great majority of the states. There will thus be a single agency, either a department of labor, industrial commission or unemployment compensation commission in each state having full responsibility for the administration of both unemployment compensation and employment offices.

Under such commission it is probable there will be a system of district and local offices in each of which there will be two distinct and separate activities carried on, the employment service with its own personnel and functions, and the unemployment compensation administration. If the present plans of the Social Security Board mature it is probable that the district and local offices of the Security Board to serve the purposes of old age insurance or benefit administration, will parallel the district and local offices of the Employment Service and the unemployment compensation administration. While each of these three functions will be administered separately the coördination of such district and local offices should be of major assistance in facilitating the effective administration of the entire program. It has been suggested that the district and local offices serving these combined purposes be called Employment offices. To the public these offices would be employment offices with unemployment compensation and possibly old age insurance divisions attached. In this manner, the employment or placement function is emphasized rather than the compensation or benefit features of the program. 


\section{Functions of the Employment Service in the Unemployment Compensation Program.}

While it is not yet possible to indicate with accuracy the provisions of the many state laws that will be passed on this subject, the development to date would seem to suggest that the Employment Service will have two major functions to discharge in the entire program:

r. Registration. The Employment Service at the present time maintains a complete registration of all unemployed and employed persons who indicate their desire to secure either public or private employment through the facilities afforded by the Service. Since July 1933 approximately 20 million individuals have registered with the various offices of the Employment Service seeking work. Some 13 million placements have been made, either on public works projects of various kinds or in private employment and there remain a very large number of individuals who are each month indicating they are still seeking work and maintaining their registration in the Employment Service.

As of December 31, 1935 there were over 8 million registrations in the active files, which means that this number of individuals were known to be actively seeking work through the facilities of these offices during December. There were some 12 million registrations in the inactive files. For each of these individuals the Employment Service has a rather complete registration record and there is available in Washington a punched card record of each such individual, indicating important items of information for purposes of identification and classification including the registration number, the age and sex of the registrants, usual occupation, industry to which attached, length of unemployment, veteran status, relief status, etc.

For purposes of identification and classification of both unemployment compensation and old age benefit records, some registration of employed persons subject to the provisions of the various state and federal acts must be secured over a period of time and extension of the registration procedure of the Employment Service through coöperation with employers, seems the logical and probable means of securing this essential registration information. The registration procedure for employed persons subject to these acts would probably vary from the present method in that representatives of the employment service would make coöperative and convenient arrangements with employers to register their employees at the place of work rather than requiring visitation at a central employment office for such purpose.

2. Certification of employment status. In order to establish the fact of unemployment and the eligibility of an insured worker for benefit, the several state acts require that an individual in applying for benefit must register at the employment service office and either accept suitable employment which is available through the facilities of the office and for which the worker is qualified, or in the absence of such work opportunity, receive a certification from the Employment Service that no suitable employment is available and the applicant is thus eligible for benefit payment.

It is difficult to over-estimate the importance of this particular function. If it becomes a mere routine certification process, the ease with which applicants may secure insurance benefits will inevitably lead to an unsupportable drain on the reserves of the compensation funds.

Care must therefore be exercised to see that every possible avenue of suitable employment is explored and made available through the Employment Service for the benefit of the applicants. 
On the other hand, if requirements for the acceptance of employment are too rigid and not carefully guarded skilled workmen might conceivably be forced to accept unsatisfactory work which would not only contribute to destroying their skill, but would break down their standard of living and lessen their chances of securing satisfactory employment in the line of work for which they were well fitted.

It is essential, therefore, that the Employment Service be in a position to secure complete information with respect to the available types of employment and render service of a character which will lead to employers' coöperation in the full utilization of the Service. It is also important that the Service develop the techniques of job analysis and improved methods in the selection of workers for referral to different types of employment, so that every available opportunity for the satisfactory adjustment and readjustment of wokers into private employment may be capitalized.

The present efforts of the United States Employment Service in coöperation with other agencies and national research groups to develop accurate job specifications, improved occupational classifications, and techniques for testing and classification of workers, must be developed in close coöperation with the work of the Social Security Board if these ends are to be served.

The exact administrative arrangements which will provide for the coördination of employment service and unemployment compensation administration will vary from state to state and the ultimate form of the Washington organization is not yet clear. It is clear to all students of the problem, however, that the two activities must be administered as a closely coördinated form of organization and at the same time every effort must be made to retain identity of functions and to promote and develop those aspects of the placement service which will contribute to the careful analysis of the labor market and the effort to secure satisfactory adjustment of individuals into private industry.

At best an unemployment compensation program is a stop gap, a form of financial protection in a period of unemployment, and the entire program should be so geared as to place the emphasis on getting people back to work in private industry in types of jobs which are likely to be as permanent as possible and well suited to the capacities and abilities of the workers. We believe that some encouragement may be drawn from the fact that proper consideration is being given to these matters in the early plans for setting up the all important program of social security in these United States. 